\title{
Efektifitas Latihan Birth Ball terhadap Efikasi Diri Primipara dengan Persalinan Normal
}

\author{
Djudju Sriwenda ${ }^{1}$, Yulinda ${ }^{1}$ \\ ${ }^{1}$ DIII Kebidanan Poltekkes Kemenkes Bandung \\ Jalan Pajajaran No.56, Pasir Kaliki, Cicendo, Kota Bandung, Jawa Barat 40171 \\ Email: sriw3nda@gmail.com
}

\begin{abstract}
Abstrak
Stress, kecemasan, dan kekhawatiran adalah faktor-faktor yang berkontribusi terhadap persepsi nyeri yang memengaruhi persalinan dan pengalaman melahirkan. Latihan birth ball merupakan pengurang rasa nyeri nonfarmakologi yang bukan hanya sebagai pengurang rasa nyeri namun juga mencoba meningkatkan komponen asuhan yang bersifat emosional dan psikologis. Efikasi diri adalah kepercayaan atau kemampuan untuk melalui proses persalinan dengan baik. Hal ini merupakan faktor penting yang memengaruhi motivasi perempuan untuk melahirkan secara normal. Tujuan penelitian adalah mengetahui efektifitas latihan birth ball terhadap efikasi diri primipara pada persalinan normal. Desain penelitian menggunakan kuasi eksperimen. Kelompok perlakuan adalah kelompok yang mendapat latihan birth ball yang dilakukan sejak kehamilan 32 minggu hingga menjelang persalinan. Waktu penelitian dari Juni - Oktober 2014 di 5 lokasi Bidan Praktik Mandiri (BPM). Pengambilan sampel menggunakan teknik consecutive sampling. Analisis data menggunakan Uji $t$ independen untuk membandingkan nilai self efficacy pada kelompok perlakuan dan kelompok kontrol yang diambil pada pengukuran self efficacy pertama kali sedangkan uji t dependen digunakan pada kedua kelompok untuk membandingkan nilai efikasi diri pada 2 kali penilaiian. Pada penelitian ini didapatkan hasil bahwa terdapat pengaruh antara latihan birth ball terhadap efikasi diri primipara pada persalinan normal, tidak ada perbedaan tingkat efikasi diri pada pembukaan $4 \mathrm{~cm}$ antara kelompok perlakuan dan kelompok kontrol, terjadi peningkatan self effikasi sebesar 6,48 point pada pembukaan $4 \mathrm{~cm}$ dan $8 \mathrm{~cm}$ ibu primipara setelah melakukan latihan birth ball. Sebaiknya latihan birth ball dilakukan sejak kehamilan trimester 3 yang dapat dilaksanakan secara terintegrasi dalam kelas ibu hamil. Tersedianya variasi untuk fasilitas latihan fisik bagi ibu hamil dan bersalin di tempat pelayanan persalinan.
\end{abstract}

Kata Kunci: birth ball, efikasi diri, persalinan, primipara

\section{Efectivity of Birth Ball Exercise on Self Efficacy of Primiparous with Normal Labor}

\begin{abstract}
Stress, fear and anxiety are the factors which having contribution to pain perception that influence labor process and birth experience. Birth ball is not only as a nonfarmacological pain relief but also increasing emotional and psychlogical care. Self effiacy is a belief or an abiity to exert her ability to pass adversity in labor process. These is an important aspect which influence women motivation to make birth normally. It was quasi-experiment research. Treatment group was given birth ball exercise since 32 weeks of gestation until before labor process. Research period was from June until October 2014 at 5 (five) privat midwife's private clinic and used consecutive sampling. The research analysis used t-independent to compare self efficacy level on control and treatment group that was taken at first self efficacy test. It also used t-dependent on those group to compare self efficacy level at second test. In conclusion, there was influence of birth ball exercise to self efficacy of primiparous with normal labor. There was no difference on self efficacy level at $4 \mathrm{~cm}$ cervic dilatation on both groups, also there was 6.48 point of self efficacy level increase at $4 \mathrm{~cm}$ and $8 \mathrm{~cm}$ cervic dilatation after doing birth ball exercise. Birth ball exercise shoud be done since third trimester of pregnancy,
\end{abstract}


which can be held integrated in antenatal class. There shoud be variety at physic exercise facility for pregnant woman and parturient at health services.

Keywords: birth ball, self efficacy, labor process, primipara

Info Artikel:

Artikel dikirim pada 20 September 2016

Artikel diterima pada 31 Oktober 2016

DOI : http://dx.doi.org/10.21927/jnki.2016.4(3).141-147

\section{PENDAHULUAN}

Stress, kecemasan dan kekhawatiran adalah faktor-faktor yang berkontribusi terhadap persepsi nyeri yang mempengaruhi persalinan dan pengalaman melahirkan (1). Strategi koping dapat membantu dalam proses manajemen nyeri. Efikasi diri memainkan peranan yang penting terhadap kemampuan perempuan dalam koping tersebut (2). Efikasi diri adalah kepercayaan atau kemampuan untuk melalui proses persalinan dengan baik. Hal ini merupakan faktor penting yang memengaruhi motivasi perempuan untuk melahirkan secara normal (1).

Seseorang dengan efikasi diri yang tinggi akan berupaya keras untuk mengerahkan kemampuannya dalam mencapai keberhasilan tanpa terbebani oleh kesulitan yang dihadapi. Pengembangan konseptual tentang efikasi diri dalam persalinan telah dilakukan oleh Lowe melalui Childbirth Self Efficacy Inventory (CBSEI) untuk mengukur kepercayaan diri dan kemampuan mengatasi proses persalinan (2)

Latihan birth ball adalah latihan atau gerakan tubuh sederhana menggunakan bola yang dapat dilakukan pada saat hamil, melahirkan, dan pasca melahirkan bertujuan sebagai pengurang rasa nyeri non farmakologi dan juga mencoba meningkatkan komponen asuhan yang bersifat emosional dan psikologis (1). Satu penelitian menyatakan latihan birth ball memberikan kontribusi dalam meningkatkan efikasi diri ibu selama persalinan dan mengurangi rasa sakit. Latihan birth ball berhasil meningkatkan kepercayaan ibu hamil terhadap kemampuannya dalam mekanisme koping persalinan (2).

Penggunaan birth ball selama persalinan mampu menurunkan tingkat nyeri karena merangsang refleks postural dan menjaga otot-otot serta menjaga postur tulang belakang dalam keadaan baik, sehingga mengurangi kecemasan, sedikitnya penggunaan pethidin, memfasilitasi penurunan kepala janin, mengurangi lamanya kala 1 serta meningkatkan kepuasaan dan kesejahteraan ibu, selain itu juga dilaporkan bahwa para ibu merasa lebih nyaman dan relaks dan $95 \%$ responden menyatakan bahwa latihan birth ball dapat meningkatkan kenyamanan $(3,4)$. Studi lain menemukan bahwa lama fase aktif persalinan (pembukaan serviks uteri) 30\% lebih pendek dan hambatan selama kala II persalinan menurun secara signifikan pada kelompok yang melakukan latihan (5). Tujuan dari penelitian ini adalah untuk melihat efektifitas latihan birth ball terhadap efikasi diri primipara pada persalinan normal.

\section{BAHAN DAN METODE}

Penelitian ini dilakukan dengan menggunakan desain quasi eksperimen, dilaksanakan di Bidan Praktik Mandiri (BPM) Wilayah Kota Bandung (BPM Teti Sulastri dan BPM Firdawarni) serta BPM Bidan Titin Kartini di Kabupaten Bandung untuk perlakuan sedangkan untuk kelompok kontrol dilakukan di BPM di Wilayah Kota Bandung (BPM Otoy Sarimanah dan BPM Sukmawati). Pemilihan tempat penelitian dilakukan berdasarkan banyaknya persalinan per bulan yaitu sekitar 30-50 persalinan. Teknik pengambilan lokasi penelitian didasarkan pada jumlah persalinan dalam 1 bulan yaitu $\geq 25$ persalinan spontan. Waktu penelitian dilakukan selama lima bulan yaitu Juni sampai dengan Oktober 2014. Pengambilan data dilakukan hingga jumlah sampel mencapai besar sampel yang ditetapkan.

Pengambilan sampel pada penelitian ini menggunakan teknik consecutive sampling yaitu semua subjek yang datang dan memenuhi kriteria inklusi dimasukkan dalam penelitian sampai jumlah subjek yang dibutuhkan terpenuhi. Jumlah besar sampel 154 terdiri dari 77 orang ibu hamil 32 minggu untuk kelompok perlakuan dan 77 orang ibu hamil 32 minggu untuk kelompok kontrol.

Kelompok perlakuan adalah kelompok yang mendapat latihan birth ball yang dilakukan sejak kehamilan 32 minggu hingga menjelang persalinan. Latihan dilakukan sebanyak 2 kali per minggu dengan 
lama latihan 20 menit setiap latihannya pada saat kehamilan, sedangkan pada saat memasuki persalinan, latihan birth ball dilakukan sesuai dengan kemampuan ibu primipara. Latihan tersebut adalah sitting (pelvic rocking forward and back, hula-hula, side to side and rocking), standing (bersandar pada bola yang menempel didinding-up and down), kneeling (memeluk boladan rocking pelvic), squatting (bersandarpadabola yang menempel pada dinding).

Kelompok kontrol yaitu kelompok ibu hamil yang melakukan senam hamil yang diselenggarakan secara rutin oleh bidan di lokasi penelitian setiap minggu sekali. Untuk memantau kepatuhan kelompok kontrol dalam melakukan senam hamil, disediakan daftar hadir yang harus diisi pada setiap sesinya.

Pengumpulan data dilakukan dengan menggunakan angket. Bagi kelompok yang mendapat perlakuan dan memenuhi kriteria inklusi dilakukan pelatihan gerakan menggunakan birth ball sesuai panduan yang terdapat dalam booklet. Sebelum mengikuti latihan birth ball ibu harus memenuhi persyaratan, yaitu: kondisi ibu dan janin dalam keadaan baik, dengan indikator denyut nadi ibu maksimal $98 \mathrm{kali} / \mathrm{menit}$ dan denyut jantung janin 120160x/menit, latihan dihentikan jika denyut nadi ibu mencapai maksimal 96 kali/menit atau ibu merasakan ada keluhan, seperti pusing, mual, kelelahan atau merasa tidak kuat melakukan latihan birth ball.

Memasuki saat persalinan, seluruh responden (kelompok perlakuan dan kelompok kontrol) diminta mengisi angket tentang efikasi diri yang dilakukan sebanyak 2 kali yaitu pada saat pembukaan serviks $<4 \mathrm{~cm}$ dan pembukaan serviks $8 \mathrm{~cm}$. Setelah itu dilakukan perbandingan dari hasil ke dua penilaian tersebut.

Tingkat efikasi diri diukur dengan menggunakan instrumen penilaian self efficacy yang diadaptasi dari childbirth self efficacy inventory dari Lowe, 1993. Sampel penelitian mengisi instrumen yang terdiri dari 16 pernyataan sebanyak dua kali, yaitu pada saat pembukaan servik $4 \mathrm{~cm}$ dan $8 \mathrm{~cm}$, dengan melingkari nilai 1 apabila tidak membantu sampai nilai 10 apabila sangat membantu ibu. Pengukuran efikasi diri yang pertama dilakukan pada pembukaan serviks $4 \mathrm{~cm}$ karena pada saat ini ibu dalam kondisi masih stabil dan baru memasuki fase aktif, sementara penilaian efikasi diri yang kedua dilakukan pada saat pembukaan serviks $8 \mathrm{~cm}$, karena fase ini merupakan fase transisi yang mana ibu merasakan perasaan gelisah yang mencolok, rasa tidak nyaman menyeluruh, bingung, frustasi, emosi meledak-ledak akibat menngkatnya kontraksi, kesadaran terhadap martabat diri menurun drastis, mudah marah, menolak hal-hal yang ditawarkan kepadanya, rasa takut semakin besar.

Tingkat efikasi diri seorang ibu bersalin dinilai dari 16 pertanyaan dengan rentang nilai 1-10. Tingkat efikasi diri dikategorikan tinggi jika jumlah nilai $\geq 112$ dan dikategorikan rendah jika jumlah nilai $<112$. Pada saat ini seseorang dapat mengerahkan kemampuannya untuk dapat mengontrol dirinya sehingga dapat beradaptasi terhadap kontraksi dan nyeri selama proses persalinan.

Latihan birth ball dicatat dalam lembar pemantauan latihan birth ball, sedangkan pembukaan serviks uteri pada proses persalinan dicatat pada lembar partograf untuk menilai kemajuan persalinan dengan indikator bertambahnya pembukaan serviks uteri pada fase aktif persalinan.

Analisis yang digunakan untuk eksperimen post test only adalah uji t independen dan uji t dependen. Uji t independen digunakan untuk membandingkan nilai self efficacy pada kelompok perlakuan dan kelompok kontrol yang diambil pada pengukuran self efficacy pertama kali yaitu pada pembukaan serviks $<4 \mathrm{~cm}$, sedangkan uji t dependen digunakan pada kedua kelompok untuk membandingkan nilai efikasi diri pada 2 kali penilaian.

Sebelum uji statistik dilakukan, uji normalitas data dilakukan dengan Kolmogorov-Smirnov Z dengan hasil yaitu nilai efikasi diri pembukaan serviks 4 dan $8 \mathrm{~cm}$ mempunyai nilai 0,001 dan 0,000 sehingga disimpulkan bahwa data tidak berdistribusi normal. Selanjutnya dilakukan uji non parametrik untuk $t$ independen menggunakan Mann-Withney antara kelompok perlakukan dan kelompok kontrol.

\section{HASIL DAN BAHASAN}

Karakteristik responden pada penelitian ini dibedakan atas usia dan pekerjaan dapat dilihat pada Tabel 1. Berdasarkan tabel tersebut terlihat bahwa usia responden pada kedua kelompok terbanyak pada rentang usia reproduksi sehat, sementara untuk pekerjaan sebagian besar adalah ibu rumah tangga.

Pada penelitian ini didapatkan bahwa sebagian besar responden berada pada masa reproduksi sehat, hanya sebagian kecil responden yang berusia $<20$ tahun, usia sangat memengaruhi seorang perempuan 
Tabel 1. Karakteristik Responden

\begin{tabular}{|c|c|c|c|c|c|}
\hline \multirow{3}{*}{ Karakteristik } & \multicolumn{4}{|c|}{ Kelompok } & \multirow{3}{*}{$\begin{array}{c}\text { Rata- } \\
\text { Rata } \\
\left(x_{ \pm} \text {SD) }\right.\end{array}$} \\
\hline & \multicolumn{2}{|c|}{ Perlakuan } & \multicolumn{2}{|c|}{ Kontrol } & \\
\hline & $f$ & $\%$ & $f$ & $\%$ & \\
\hline \multicolumn{6}{|l|}{ Usia } \\
\hline$<20$ tahun & 18 & 23 & 13 & 17 & \\
\hline 20-35 tahun & 56 & 73 & 64 & 83 & \\
\hline$>35$ tahun & 3 & 4 & 0 & 0 & 3,91 \\
\hline \multicolumn{6}{|l|}{ Pekerjaan } \\
\hline Ibu Rumah Tangga & 65 & 84 & 72 & 93 & \\
\hline Pegawai swasta & 8 & 10 & 3 & 4 & \\
\hline Wiraswasta & 2 & 3 & 2 & 3 & \\
\hline Mahasiswa & 2 & 3 & 0 & 0 & \\
\hline
\end{tabular}

Sumber: Data BPM Kota Bandung dan Kab Bandung Tahun 2014

dalam menghadapi kehamilan dan persalinan baik fisik ataupun psikologis. Seseorang dengan usia <20 tahun dimungkinkan belum siap secara psikologis dalam menghadapi kehamilan ataupun persalinan. Kesiapan untuk hamil ditentukan oleh 3 faktor yaitu kesiapan fisik, mental, dan ekonomi. Secara umum perempuan dikatakan siap untuk hamil jika sudah berusia di atas 20 tahun. Secara psikis, seseorang dengan usia $<20$ tahun kurang mampu dalam pengambilan keputusan klinis. Selain itu kehamilannya kadang disertai dengan penyakit/ kondisi yang tidak normal, begitu pula dengan outcome persalinan berupa persalinan prematur ataupun berat bayi rendah (6).

Tabel 2. Lama Fase Aktif Persalinan

\begin{tabular}{|c|c|c|c|c|}
\hline \multirow{3}{*}{$\begin{array}{c}\text { Lama Fase } \\
\text { Aktif }\end{array}$} & \multicolumn{4}{|c|}{ Kelompok } \\
\hline & \multicolumn{2}{|c|}{ Perlakuan } & \multicolumn{2}{|c|}{ Kontrol } \\
\hline & $f$ & $\%$ & $f$ & $\%$ \\
\hline$\leq 6$ jam & 64 & 83 & 64 & 83 \\
\hline$>6$ jam & 13 & 17 & 13 & 17 \\
\hline Jumlah & 77 & 100 & 77 & 100 \\
\hline
\end{tabular}

Sumber: Data BPM Kota Bandung dan Kab Bandung Tahun 2014

Pemantauan lamanya fase aktif persalinan dilakukan dengan menggunakan partograf, yang diisi setelah bidan melakukan pemeriksaan dalam untuk menilai pembukaan serviks. Tabel 2 ini menunjukkan bahwa lamanya fase aktif pada kedua kelompok adalah sama, yaitu kurang atau sama dengan 6 jam sebanyak $83 \%$.

Berdasarkan grafik partograf, lama kala 1 fase aktif baik untuk primipara ataupun multipara adalah 6 jam dengan mempertimbangkan penambahan dilatasi serviks sebesar $1 \mathrm{~cm}$ dalam 1 jam. Penambahan dilatasi serviks berbeda antara primipara dan multipara. Untuk primipara penambahan dilatasi serviks adalah $1 \mathrm{~cm}$ dalam 1 jam sedangkan multipara adalah1 $\mathrm{cm}$ dalam 30 menit $(7,8)$.

Pada penelitian ini didapatkan lama kala 1 $\leq 6$ jam pada kedua kelompok adalah $83 \%$, hal ini menunjukkan bahwa lebih dari dua pertiga responden berada pada kondisi normal. Pada fase aktif pembukaan serviks $4 \mathrm{~cm}$, perempuan merasa akan bersalin dan memiliki anggapan akan mendapatkan bantuan dan rasa aman serta memiliki koping yang baik. Perempuan mampu berpikir secara rasional dan mampu kooperatif dengan penolong persalinan (9).

Tabel 3. Tingkat Efikasi diri Ibu Bersalin

\begin{tabular}{ccccc}
\hline & \multicolumn{4}{c}{ Kelompok } \\
\cline { 2 - 5 } Tingkat Efikasi & \multicolumn{2}{c}{ Perlakuan } & \multicolumn{2}{c}{ Kontrol } \\
\cline { 2 - 5 } Diri & $\mathbf{f}$ & $\%$ & $\mathbf{f}$ & $\%$ \\
\hline Tinggi & 67 & 87 & 64 & 83 \\
Rendah & 10 & 13 & 13 & 17 \\
Jumlah & 77 & 100 & 77 & 100 \\
\hline
\end{tabular}

Sumber: Data BPM Kota Bandung dan Kab Bandung Tahun 2014

Tabel 3 menunjukkan bahwa $>80 \%$ responden baik kelompok perlakuan maupun kelompok kontrol memiliki efikasi diri yang tinggi. Persalinan merupakan hubungan saling memengaruhi yang rumit antara dorongan psikologis dan fisiologis dalam diri seorang perempuan pada proses kelahiran bayi.

Kontraksi uterus pada persalinan bersifat unik mengingat kontraksi ini merupakan kontraksi otot fisiologis yang menimbulkan nyeri padatubuh. Kontraksi ini berada dibawah pengaruh saraf intrinsik sehingga perempuan tidak memiliki kendali fisiologis terhadap frekuensi dan durasi kontraksi (9).

Perempuan yang sedang dalam keadaan takut dan tidak mengetahui apa yang terjadi pada dirinya serta tidak dipersiapkan dengan teknik relaksasi dan pernafasan untuk mengatasi kontraksi, akan bergerak tidak terkendali walaupun kontraksi tersebut ringan. Sebaliknya, jika seorang perempuan dipersiapkan dalam menghadapi pengalaman persalinan dan mendapat dukungan dari tenaga profesional, maka akan menunjukkan proses pengendalian diri pada saat terjadi kontraksi yang hebat (10).

Efikasi diri adalah proses kognitif yang memengaruhi motivasi seseorang untuk berperilaku. 
Seberapa baik seseorang dapat menentukan atau memastikan terpenuhinya motif mengarah pada tindakan yang diharapkan sesuai situasi yang dihadapi, yakni adanya dilatasi serviks uteri fisiologis yang disertai ketidaknyaman hingga mencapai dilatasi serviks lengkap. Keyakinan akan seluruh kemampuan ini meliputi kepercayaan diri, kemampuan menyesuaikan diri, kemampuan kognitif, kecerdasan, dan motivasi untuk bertindak pada situasi yang penuh tekanan. Efikasi diri akan berkembang berangsur-angsur secara terus menerus sejalan dengan meningkatnya kemampuan dan bertambahnya pengalaman-pengalaman yang berkaitan (11).

Tabel 4. Pengaruh Latihan Birth Ball terhadap Efikasi Diri pada Pembukaan $4 \mathrm{~cm}$

\begin{tabular}{lccc}
\hline Tingkat Self efficacy & $\mathbf{n}$ & Mean & p-value \\
\hline Kelompok Perlakuan & 77 & 124,50 & 0,202 \\
Kelompok Kontrol & 77 & 120,77 & \\
\hline
\end{tabular}

Sumber: Data BPM Kota Bandung dan Kab Bandung Tahun 2014

Tabel 4 menunjukkan bahwa tidak ada pengaruh signifikan latihan birth ball terhadap efikasi diri. Proses persalinan terbagi dalam 2 fase yaitu fase laten dan fase aktif. Fase aktif dibagi menjadi fase percepatan dan fase transisi. Fase latent adalah keadaan saat dilatasi serviks mulai membuka hingga $3 \mathrm{~cm}$, sedangkan fase aktif adalah dilatasi serviks mencapai $4 \mathrm{~cm}$ hingga 10 $\mathrm{cm}$. Fase percepatan adalah kondisi saat terjadi penambahan dilatasi serviks yang cepat dari $4 \mathrm{~cm}$ hingga $8 \mathrm{~cm}$ (terjadi antara 2-3 jam) sedangan fase transisi adalah fase saat dilatasi serviks $8 \mathrm{~cm}$ hingga $10 \mathrm{~cm}$ dan umumnya mengambil waktu yang agak lama (masa penurunan/pelambatan).

Latihan birth ball bertujuan untuk mengurangi nyeri persalinan dan mempercepat penurunan kepala janin sehingga diharapkan ibu lebih siap dan tenang dalam menghadapi persalinan serta persalinan akan berlangsung lebih cepat $(3,4,12)$. Dengan latihan birth ball selama 30 menit, nyeri persalinan dapat berkurang dan menurunkan penggunaan pethidin (1).

Uji t dependen bertujuan untuk melihat perbedaan tingkat efikasi pada pembukaan $4 \mathrm{~cm}$ dan 8 $\mathrm{cm}$. Dari uji tersebut dapat disimpulkan ada perbedaan yang signifikan antara nilai efikasi diri pada pembukaan serviks $<4 \mathrm{~cm}$ dengan nilai efikasi diri pada pembukaan serviks $8 \mathrm{~cm}$ pada ibu hamil yang melakukan latihan birth ball.
Tabel 5. Perbedaan Self Efficacy Ibu Bersalin saat Pembukaan Serviks $4 \mathrm{~cm}$ dan $8 \mathrm{~cm}$

\begin{tabular}{cccc}
\hline Paparan & \multicolumn{2}{c}{ Mean Nilai Self Efficacy } & p-value \\
\cline { 2 - 3 } & $\mathbf{4} \mathbf{~ c m}$ & $\mathbf{8} \mathbf{~ c m}$ & \\
\hline Latihan Birth Ball & 124,50 & 130,02 & \\
Senam Hamil & 120,77 & 118,68 & 0,000 \\
\hline
\end{tabular}

Sumber: Data BPM Kota Bandung dan Kab Bandung Tahun 2014

Pada penelitian ini didapatkan perbedaan yang signifikan pada tingkat efikasi diri antara kelompok ibu yang melakukan latihan birth ball dengan kelompok kontrol pada saat dilatasi serviks $4 \mathrm{~cm}$ dan $8 \mathrm{~cm}$. Hal ini menunjukkan bahwa dengan adanya kelompok latihan birth ball, ibu mampu memahami apa yang akan terjadi dan siap dalam menghadapi kontraksi yang berikutnya. Penelitian yang dilakukan oleh Gau dkk menunjukkan bahwa latihan birth ball dapat mengurangi rasa nyeri,dapat mengurangi penggunaan analgesia, mengalami kala I yang lebih pendek dan penurunan angka persalinan dengan operatif (2).

Penggunaan birth ball membuat ibu merasa aman dan nyaman dalam bergerak sehingga memudahkan janin untuk bergerak di dalam panggul. Hasil penelitian yang sama ditunjukkan oleh Vankatesan, bahwa primigravida yang mendapat perlakuan berupa latihan birth ball memiliki nilai koping yang lebih tinggi dibandingkan dengan kelompok kontrol (10). Hal yang sama dikemukakan oleh Taavoni, et al yang menyimpulkan bahwa latihan birth ball dapat mengurangi rasa nyeri. Hal ini ditunjukkan dengan penelitian mengenai kelompok perlakuan yang memiliki nilai rata nyeri yang lebih rendah dibandingkan dengan kelompok kontrol (12).

Effikasi diri yang baik akan mengarahkan ibu pada kondisi mental yang stabil, sehingga mampu menerima arahan. Ibu hamil dan bersalin yang telah mendapatkan persiapan menghadapi persalinan dalam bentuk latihan birth ball dan psikologis, akan mendapatkan proses pembelajaran dan pengalaman, sehingga dapat lebih mempersiapkan diri menjalani kontraksi. Untuk selanjutnya dapat beradaptasi terhadap nyeri dan ketidaknyaman selama proses persalinan $(11,13)$.

Efikasi diri ini sangat menentukan besarnya keyakinan mengenai kemampuan yang dimiliki oleh setiap individu untuk melakukan proses belajarnya, sehingga dapat mencapai hasil yang optimal. Individu yang memiliki efikasi diri yang tinggi akan mampu mengatur dirinya untuk belajar. Ada keyakinan dalam dirinya untuk mampu menyelesaikan tugas yang 
sulit saat belajar, dan keyakinan untuk mampu dalam menyelesaikan berbagai macam tugas serta usaha yang keras untuk menyelesaikan semua tugas. Hal tersebut akan dapat mendorong individu untuk dapat merencanakan aktivitasnya saat persalinan, berusaha untuk memonitornya serta memanipulasi lingkungan sedemikian rupa guna mendukung aktivitasnya. Dengan demikian, dapat diketahui apabila efikasi diri yang dimiliki individu rendah, dapat menyebabkan hambatan dalam proses adapatasinya meskipun individu tersebut memiliki potensi yang besar. Efikasi diri yang tinggi menyebabkan munculnya self regulated learning yang tinggi $(14,15)$.

Bidan sebagai pemberi asuhan dalam persalinan, memiliki tugas untuk memfasilitasi ibu selama proses persalinan dengan senantiasa memberikan dukungan baik berupa fisik ataupun psikologis. Dukungan fisik berupa menyiapkan ruangan yang membuat ibu merasa nyaman, aman dan tidak asing, pemberian teknik pengurang rasa nyeri non farmakologi, sementara untuk dukungan psikologis berupa memberi kesempatan keluarga untuk mendampingi pada saat persalinan, sikap bidan yang empati dan menghargai (9).

Faktor lainnya yang mampu mempengaruhi self regulated learning adalah dukungan sosial keluarga yang memiliki peranan cukup penting karena keluarga merupakan orang yang terdekat dengan individu. Apabila individu mendapatkan dukungan emosi dari keluarganya, saat menghadapi rintangan dalam belajar maka seseorang akan mendapatkan dukungan dari keluarganya sehingga tetap merasa lebih percaya diri dan tetap mampu merencanakan dan mengontrol kegiatan belajarnya serta memanfaatkan lingkungannya. Saat seorang ibu bersalin diberikan dukungan penghargan yang sifatnya positif, misalnya dalam bentuk pujian dari keluarganya, ibu bersalin akan merasa dirinya cukup berharga sehingga saat belajar ia memiliki dorongan untuk mengatur, memonitor menyeleksi lingkungan yang kondusif untuk proses persalinan. Dukungan informasi yang diberikan oleh keluarga juga akan membantu seseorang untuk mendapatkan informasi baik $(15,16)$.

\section{SIMPULAN DAN SARAN}

Berdasar penelitian ini, dapat disimpulkan terdapat pengaruh antara latihan birth ball terhadap efikasi diri primipara pada persalinan normal. Tidak ada perbedaan tingkat efikasi diri ibu bersalin pada pembukaan $4 \mathrm{~cm}$ antara kelompok latihan birth ball dan kelompok kontrol. Terjadi peningkatan efikasi diri sebesar 6,48 point pada pembukaan $4 \mathrm{~cm}$ dan $8 \mathrm{~cm}$ ibu primipara setelah melakukan latihan birth ball.

Saran yang diberikan untuk para praktisi bidan adalah latihan fisik berupa latihan birth ball sebaiknya dilakukan sejak kehamilan trimester 3 yang dapat diselenggarakan secara terintegrasi dalam kelas ibu hamil Tersedianya variasi untuk fasilitas latihan fisik bagi ibu hamil dan bersalin di tempat pelayanan persalinan.

\section{RUJUKAN}

1. Leung RWC, Li JFP, Leung MKM, Fung BKY, Fung LCW, Tai SM, et al. Efficacy of Birth Ball Exercises on Labour Pain Management. Hong Kong Med J = Xianggang yi xue za zhi [Internet]. 2013 Oct 22;19(5):393-9. Available from: http://www.hkmj. org/abstracts/v19n5/393.htm.

2. Gau M-L, Chang C-Y, Tian S-H, Lin K-C. Effects of Birth Ball Exercise on Pain and Self-Efficacy during Childbirth: a Randomised Controlled Trial in Taiwan. Midwifery [Internet]. 2011 Dec;27(6):e293-300. Available from: http://www.ncbi.nlm.nih.gov/ pubmed/21459499.

3. HAU W-L, TSANG S-L, KWAN W, MAN LSK, HO L-F, LAI F-K, et al. The Use of Birth Ball as a Method Pain Management in Labour. J.Gynaecol Obstet Midwifery. HKJGOM [Internet]. 2012;12(1):63-8. Available from: http://hkjgom. org/sites/default/files/pdf/v12-p63-birth-ball.pdf.

4. KWANWS, CHANS, LIW.The Birth Ball Exprience: Outcome Evaluation of The Intrapartum Use of Birth ball. HKJGOM [Internet]. 2011;11(1):59-64. Available from: http://www.hkjgom.org/sites/ default/files/pdf/v11-p59-thebirth.pdf.

5. Stevenson L. Exercise in pregnancy. Part 1: Update on pathophysiology. Can Fam Physician [Internet]. 1997 Jan;43:97-104. Available from: http://www.ncbi.nlm.nih.gov/pubmed/9626428.

6. Effendi, Makhfudi. Keperawatan Kesehatan Komunitas: Teori dan Praktik dalam Keperawatan. Jakarta: Salemba; 2009.

7. Prawiraharjo S. IImu Kebidanan. Jakarta: Yayasan Bina Pustaka; 2006.

8. Pusdiknakes-WHO. Asuhan Intrapartum. Jakarta: Pusdiknakes; 2003.

9. Varney H, Kriebs JM, Gegor CL. Buku Ajar Asuhan Kebidanan. EGC; 2008. 
10. Venkatesan L. Effectiveness of birthing ball upon labor pain and coping in primi gravid women. [Internet]. 2013 [cited 2014 Apr 17]. p. 1-27. Available from: http://medicine.nus.edu. sg/nursing/events/inc2013/presentation/CS-A/ A08_Latha Venkatesan.pdf.

11. Sahar P. Effikasi Diri [Internet]. Available from: saharpratama.com.

12. Taavoni $\mathrm{S}$, Abdolahian S, Haghani H, Neysani L. Effect of Birth Ball Usage on Pain in the Active Phase of Labor: A Randomized Controlled Trial. J Midwifery Womens Health [Internet]. 2011 Mar;56(2):137-40. Available from: http://doi.wiley. com/10.1111/j.1542-2011.2010.00013.x.

13. Björk E, Thorildsson M. Childbirth Self-Efficacy Inventory in Tanzania - a pilot study. Dept. of Health and Social Sciences. Caring SciencesSexual, reproductive and perinatal Health Midwifery programme. DIVA [Internet]. 2007;1-37. Available from: http://www.diva-portal.se/smash/ get/diva2:518410/FULLTEXT01.pdf.
14. Tanglakmankhong K, Perrin NA, Lowe NK. Childbirth Self-Efficacy Inventory and Childbirth Attitudes Questionnaire: psychometric properties of Thai language versions. J Adv Nurs [Internet]. 2011 Jan;67(1):193-203. Available from: http://doi.wiley.com/10.1111/ j.1365-2648.2010.05479.x.

15. Jeschke E, Ostermann T, Dippong N, Brauer $\mathrm{D}$, Matthes H. Psychometric properties of the Confidence and Trust in Delivery Questionnaire (CTDQ): a pilot study. BMC Womens Health [Internet]. 2012 Dec 1;12(1):26. Available from: http://bmcwomenshealth.biomedcentral.com/ articles/10.1186/1472-6874-12-26.

16. Dencker A, Taft C, Bergqvist L, Lilja H, Berg M. Childbirth experience questionnaire (CEQ): development and evaluation of a multidimensional instrument. BMC Pregnancy Childbirth [Internet]. 2010 Dec 10;10(1):81. Available from: http:// bmcpregnancychildbirth.biomedcentral.com/ articles/10.1186/1471-2393-10-81. 